Vol. 7 (1998): 161-179.

\title{
Changes in the thermal growing season in Nordic countries during the past century and prospects for the future
}

\author{
Timothy R. Carter \\ Agricultural Research Centre of Finland, Plant Production Research. Office address: Finnish Meteorological \\ Institute, PO Box 503, FIN-00101 Helsinki, Finland, e-mail: tim.carter@fmi.fi
}

The start, end, duration and intensity of the thermal growing season (the period with mean daily temperatures exceeding $5^{\circ} \mathrm{C}$ ) during the past century (1890-1995) was analysed at nine sites in the Nordic region. Statistical comparisons were made between three adjacent 35 -year periods. The results indicate that the growing season lengthened considerably at all sites between 1891-1925 and 1926-1960. Lengthening has continued at a slower rate up to the present at the eight Fennoscandian sites but not at the Icelandic site. In contrast, the intensity of the growing season, expressed by effective temperature sum above $5^{\circ} \mathrm{C}$, which increased at all sites between the first two periods, has decreased slightly at all locations except Turku in recent decades.

Under three scenarios, representing the range of estimated greenhouse gas-induced warming by the 2050 s, the growing season is expected to lengthen at all sites. For a "Central" scenario, the greatest lengthening is computed for southern and western Scandinavia (7-8 weeks) with smaller changes in Finland ( 4 weeks) and Iceland ( 3 weeks).

With a lengthening growing season during the past century in Fennoscandia, there are likely to have been impacts on natural and managed ecosystems. Some evidence of recent biotic and abiotic effects already exists, but other indicators of long-term change remain to be analysed.

Key words: climate change, duration, effective temperature sum, impact, indicators

\section{Introduction}

During the past century developments in agricultural management and technology have revolutionised production potential, with the Nordic countries among the world leaders in embracing these advances. However, in spite of this progress much of the region still finds itself at a disadvantage compared with other areas of central and southern Europe due to a limiting factor that currently defies technological ingenuity: the short growing season.

In the Nordic region the growing season is 


\section{AGRICULTURAL AND FOOD SCIENCE IN FINLAND}

\section{Seminar in honour of the 100th anniversary of MTT}

largely temperature-limited, and is conventionally represented as the period during which the surface mean daily air temperature exceeds $5^{\circ} \mathrm{C}$. The physiological significance of this period differs among plant types. It is most relevant to perennial species that are exposed to the weather throughout the year, such as trees, shrubs and some grasses. It is less meaningful (though still relevant) in relation to annual crops, many of which are sown after the start and harvested before the end of the period. For these species, especially cereals, oilseed and legumes (and to a lesser extent tubers and root crops, which are harvested later), it is necessary to distinguish between the growing "season", which is the entire period in which growth can theoretically take place, and the growing "period", which is the actual period of growth.

The length of the growing season is a natural indicator of the thermal climate, varying both spatially (from over 220 days in southern Denmark to less than 100 days in the marginal rangelands of Iceland and northern and upland Fennoscandia) and from year to year. However, it describes only one facet of thermal suitability for plant growth: duration. It does not indicate the intensity of the season, which can be described using mean temperature or a measure of accumulated temperature (effective temperature sum - ETS). In fact, as is shown below, the duration of the season may bear little relation to its intensity.

This paper focuses on variations in growing season characteristics in the Nordic region during the past century and prospects for the future. The following section describes methods for deriving growing season duration and the data sets employed in this analysis. Subsequently, the results of an analysis of growing season duration and ETS at nine sites in the Nordic region are presented for the period 1890-1995, along with some estimates of possible future changes in duration under scenarios of greenhouse gasinduced climate change. Finally, the implication of the results is discussed in relation to observed changes in plant behaviour and other indicators of biotic and abiotic response to climate.

\section{Material and methods}

\section{The thermal growing season}

The active growing season is conventionally defined as that period during which the temperature and soil moisture conditions are adequate for crop growth. In the Nordic region, the major control on the growing season is low temperatures during the winter part of the year. This cold period is usually associated with protracted snow cover and frozen soil conditions, especially away from the milder coastal regions. By convention, the season for active plant development and growth in the Nordic countries has long been calculated as the period during which mean daily air temperatures remain above $5^{\circ} \mathrm{C}$.

Arguments for adopting this threshold include:

(i) its approximation to the mean temperature at which significant growth and development commences across a range of plant species including trees (Sarvas 1972), natural vegetation (Heikinheimo and Lappalainen 1997) and agricultural crops (Lallukka et al. 1978);

(ii) its widespread adoption as a base temperature for computing ETS, a measure of thermal time that can be related to plant development (see references in (i)); and

(iii) its approximation to the mean temperature at which continuous snowcover and soil frost disappear in many inland areas, marking the earliest opportunity for spring sowing of annual crop species.

However, the threshold is arbitrary and highly generalised. Other thresholds have been applied for computing the growing season outside the Nordic region, including $5.6^{\circ} \mathrm{C}\left(42^{\circ} \mathrm{F}\right.$ - Meteorological Office 1965) in the United Kingdom, $6^{\circ} \mathrm{C}$ in the UK (Taylor 1976) and France (AGPM 1987 ) and $4.4^{\circ} \mathrm{C}$ in various countries at northern latitudes (Nuttonson 1955). Moreover, some plants are known to commence development at temperatures lower than $5^{\circ} \mathrm{C}$, such as winter and spring cereals (Gallagher 1979, Kleemola 1991, 
Vol. 7 (1998): 161-179.

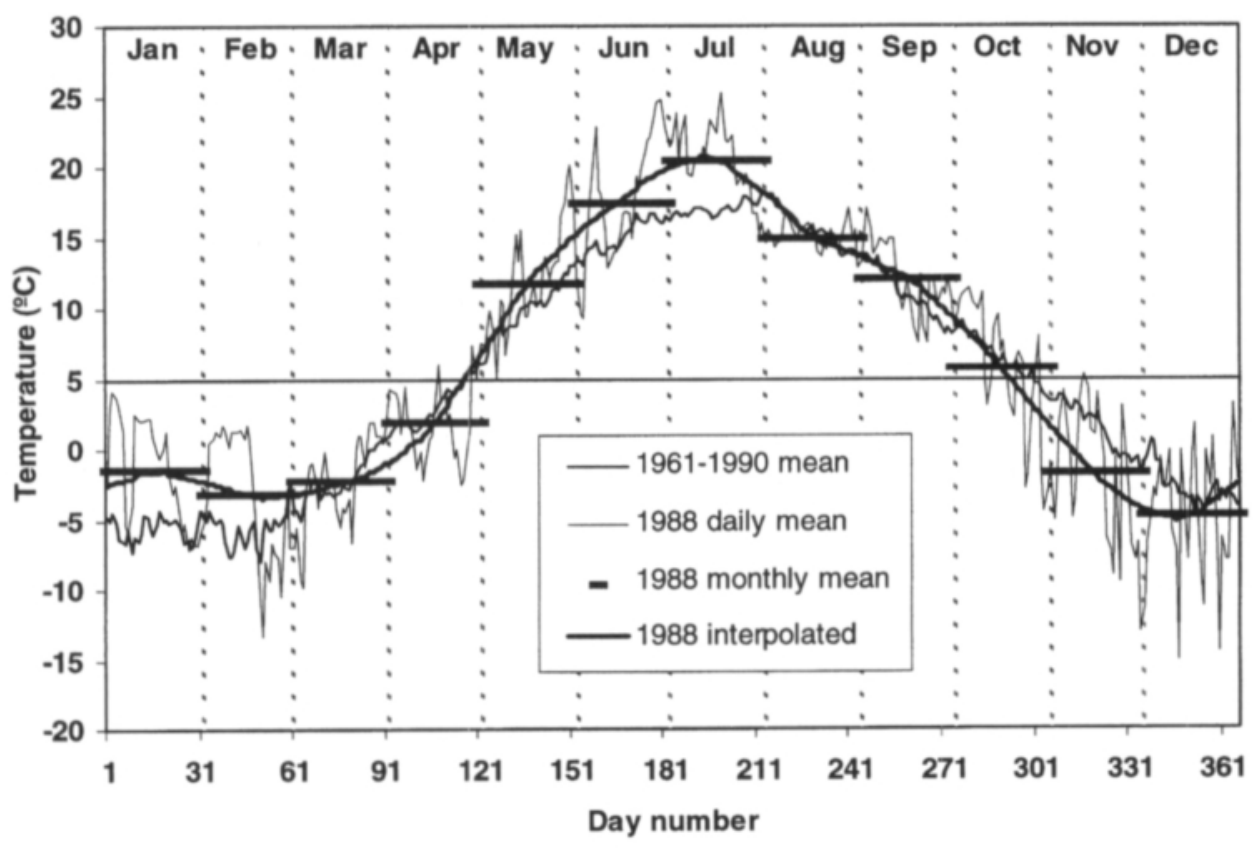

Fig. 1. Air temperature at Helsinki, Kaisaniemi: 1961-1990 mean daily, 1988 daily mean, 1988 monthly mean (horizontal lines) and 1988 daily means interpolated from monthly means using the Brooks (1943) method. Also shown is the $5^{\circ} \mathrm{C}$ threshold temperature.

Saarikko and Carter 1996) and potato (Kooman 1996). Other crops like maize (Hough 1975, Goudriaan 1988, AGPM 1987), sunflower (CETIOM 1986) or soya bean (CETIOM 1987) require temperatures higher than $5^{\circ} \mathrm{C}$. Finally, the measure is exclusively temperature-based and disregards other constraints on the growing season, especially moisture availability, which can be important during regional droughts in some seasons, but is usually regarded as a secondary constraint in the Nordic countries, and the occurrence of damaging frost, which severely curtails the effective growing period in some years and regions.

Notwithstanding the above caveats, the $5^{\circ} \mathrm{C}$ threshold represents a convenient measure, widely accepted and applied in the Nordic region. It is also advocated for defining the thermal component of a growing season measure adopted by the United Nations Food and Agriculture Organization (FAO 1978) and has subsequently been applied in global studies to model regional agri- cultural productivity potential (Leemans and Solomon 1993).

\section{Method of computation}

Computation of the index is straightforward when using long-term means of daily temperature, which generally display a smooth seasonal curve. An example is presented in Figure 1 for the 1961-1990 period at Helsinki. However, in any individual year the spring and autumn periods are usually characterised by frequent departures above and below the $5^{\circ} \mathrm{C}$ threshold. Thus, in order to compute the length of the growing season from daily temperatures, certain rules are commonly applied to avoid including warm spells in early spring or late autumn that are separated from the main growing season by prolonged colder conditions. For example, a method applied in Finland specifies that the growing season starts when daily mean temperatures first 


\section{AGRICULTURAL AND FOOD SCIENCE IN FINLAND}

Seminar in honour of the 100th anniversary of MTT

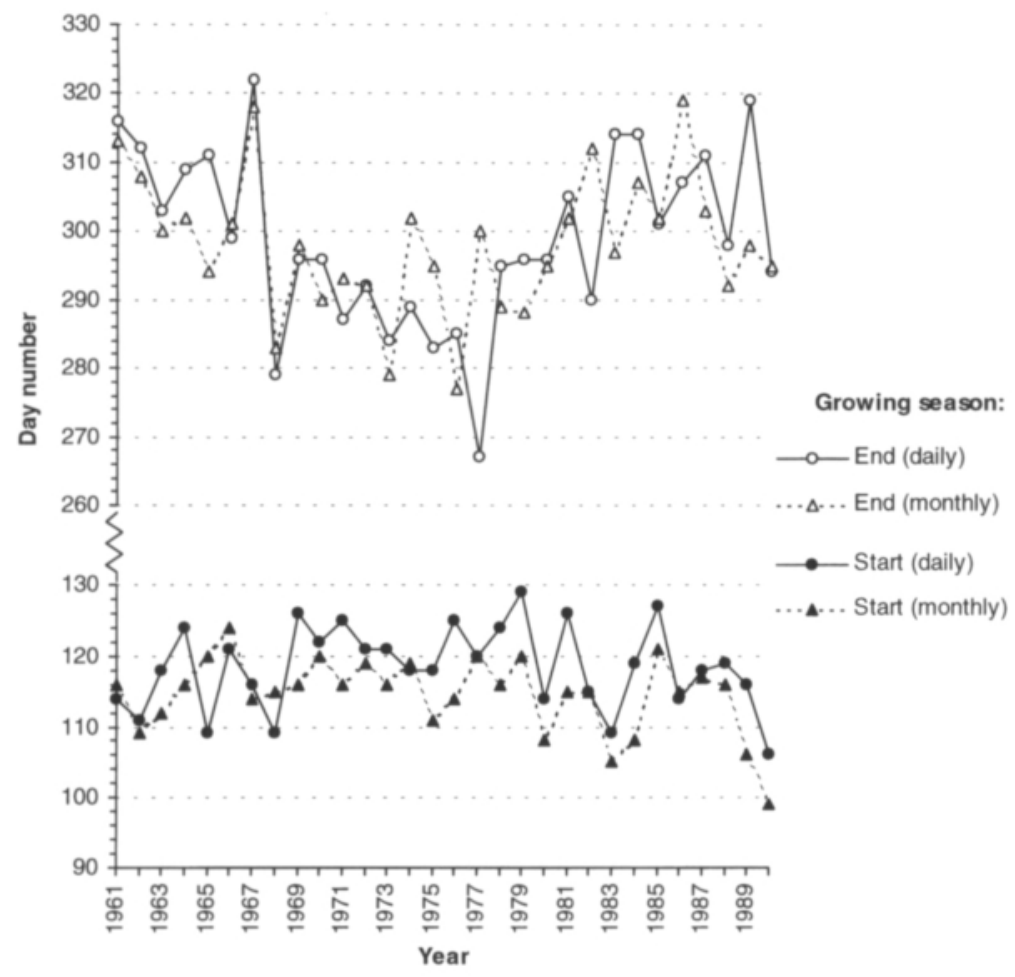

Fig. 2. Start and end dates of the thermal growing season at Helsinki (Kaisaniemi), 1961-1990, computed using the "daily" and "monthly" methods (see text for explanation). exceed $5^{\circ} \mathrm{C}$ for at least 5 consecutive days in the spring and there is less than 50\% snow cover in open areas (Venäläinen and Nordlund 1988). The season ends when the 10-day running mean of mean daily temperature falls below $5^{\circ} \mathrm{C}$.

The method is illustrated in Figure 1 using the 1988 daily mean temperature curve for Helsinki, which exceeded $5^{\circ} \mathrm{C}$ on one occasion (17 April/day 107) before commencement of the growing season on 28 April (day 118) and fell below $5^{\circ} \mathrm{C}$ twice (11-12 and 18-20 October) before the end of the growing season proper on 24 October (day 297). Nonetheless, exceptions may occur even with these definitions, and the official duration of the growing season still requires expert verification before it can be used in other applications such as calculation of ETS.

This study is concerned with century-scale variations in growing season duration. Unfortunately, there are few sites in the Nordic region for which daily mean temperature data have been computer coded over such long periods, so it was not possible to estimate the growing season directly from daily data. Instead, an approximate method of computing the growing season was adopted employing monthly mean observations which are available over a network of sites in the region.

The "monthly" method involves fitting a sine curve to the monthly mean temperatures for groups of 3 consecutive months in an approach proposed by Brooks (1943). This produces a smooth curve of daily temperatures through the monthly mean values, which can be used to estimate the start and end of the growing season. The procedure is illustrated for 1988 monthly mean temperatures at Helsinki in Figure 1, where the interpolated daily temperatures are plotted alongside the original daily mean observations. In this example, the start of the growing season using the smoothed daily temperatures occurs on 25 April or day 115 (compared with 28 April/day 118 using the original daily se- 
Vol. 7 (1998): 161-179.

Table 1. Meteorological stations supplying temperature data used in the analysis (locations are shown in Fig. 3). WMO no. is the official World Meteorological Organization code number for the station.

\begin{tabular}{lcllrl}
\hline Site & WMO no. & Country & Location & Alt.(m) & Period \\
\hline Stykkishólmur & 4013 & Iceland & $65^{\circ} 05^{\prime} \mathrm{N}, 22^{\circ} 44^{\prime} \mathrm{W}$ & 8 & $1890-1996$ \\
Nordby & - & Denmark & $55^{\circ} 26^{\prime} \mathrm{N}, 8^{\circ} 24^{\prime} \mathrm{E}$ & 5 & $1890-1995$ \\
Ferder Fyr & 1482 & Norway & $59^{\circ} 02^{\prime} \mathrm{N}, 10^{\circ} 32^{\prime} \mathrm{E}$ & 6 & $1890-1995$ \\
Falsterbo & 2616 & Sweden & $55^{\circ} 23^{\prime} \mathrm{N}, 12^{\circ} 49^{\prime} \mathrm{E}$ & 5 & $1890-1996$ \\
Uppsala & 2462 & Sweden & $59^{\circ} 51^{\prime} \mathrm{N}, 17^{\circ} 37^{\prime} \mathrm{E}$ & 13 & $1722-1997$ \\
Stockholm & 2485 & Sweden & $59^{\circ} 20^{\prime} \mathrm{N}, 18^{\circ} 03^{\prime} \mathrm{E}$ & 44 & $1756-1995$ \\
Turku & 2972 & Finland & $60^{\circ} 31^{\prime} \mathrm{N}, 22^{\circ} 16^{\prime} \mathrm{E}$ & 51 & $1890-1997$ \\
Helsinki & 2978 & Finland & $60^{\circ} 10^{\prime} \mathrm{N}, 24^{\circ} 57^{\prime} \mathrm{E}$ & 4 & $1829-1997$ \\
Kajaani & 2897 & Finland & $64^{\circ} 17^{\prime} \mathrm{N}, 27^{\circ} 40^{\prime} \mathrm{E}$ & 132 & $1890-1997$ \\
\hline
\end{tabular}

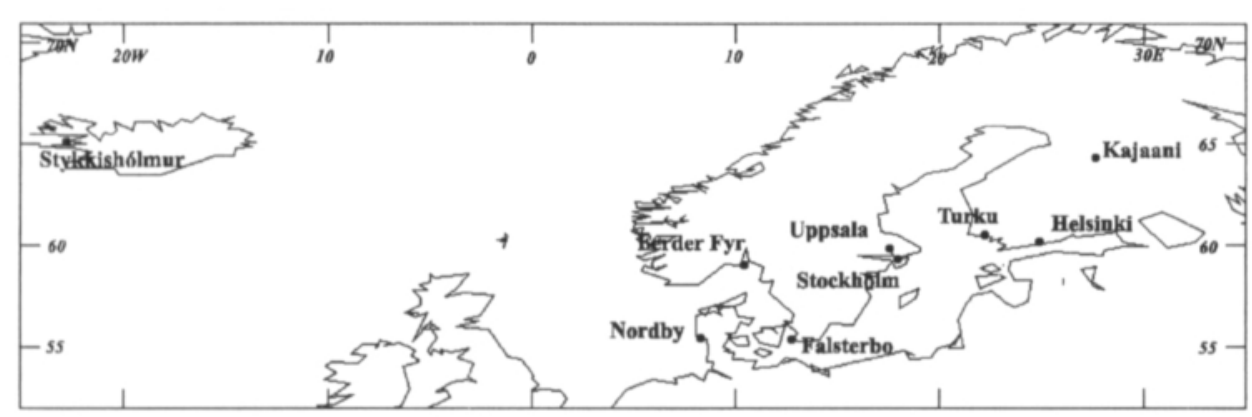

Fig. 3. Location of the meteorological stations used in this study.

ries) and the end of the growing season falls on 18 October/day 291 (compared with 24 October/day 297), giving a growing season length of 176 days (179 days).

A comparison of the "daily" and "monthly" methods of computing the growing season has been conducted for Helsinki over the 1961-1990 period (Fig. 2). On average, the monthly method produced a slightly shorter season than the daily method (mean difference -3 days; standard deviation 11.3 days), though in some years there can be differences of several weeks. These differences are primarily due to departures of daily temperatures above and below the temperature threshold during the transition seasons, which are smoothed out using the monthly method. Arguably, because it employs smoothed tem- peratures, the monthly method provides a more consistent and reliable indicator of the general march of seasonal temperature than the daily method, enabling it to be applied in detecting general trends over the long term. The monthly method is used throughout the analysis presented in the remainder of this paper. It is also used to define the growing season for computing effective temperature sum above $5^{\circ} \mathrm{C}$ :

$$
\begin{aligned}
& \text { ETS }=\sum_{i=G S S}^{G S E} \delta_{i}\left(\bar{T}_{i}-5\right) \\
& \delta_{i}=0 \text { if } \bar{T}_{i}<5 \\
& \delta_{i}=1 \text { if } \bar{T}_{i} \geq 5
\end{aligned}
$$

where GSS and GSE are the start and the end of the thermal growing season, respectively, and $\bar{T}_{i}$ is the mean temperature on day $i$. 


\section{AGRICULTURAL AND FOOD SCIENCE IN FINLAND}

\section{Seminar in honour of the 100th anniversary of MTT}

\section{Climatological data}

The study employs century-long monthly mean temperature time series from nine sites across the Nordic region (Table 1 and Fig. 3), forming part of the North Atlantic Climatological Dataset (Frich et al. 1996). Two criteria were important in selecting the sites analysed here:

(i) They should be relatively homogeneous over time, with few disturbances to the records due to relocations, instrument changes, altered measurement times, and urbanisation or other environmental effects. Six of the nine sites are reported as meeting this specification by Frich et al. (1996). Three others were selected for their long duration (see below).

(ii) They should be fairly representative of the main agricultural regions of each country, to enable comparisons of growing season characteristics with long-term statistics of crop production. Stykkishólmur was selected to represent the agricultural climate of Iceland following Bergthórsson et al. (1988). The other sites were chosen by visual comparison between the site location and a recent gridded 10' x 10' arable land use map of Europe (de Smet and Heuvelmans 1997), though the Nordby site is more maritime than typical agricultural sites in Denmark (J. Olesen, pers. comm. 1998) and Kajaani was selected to illustrate a marginal site north of the major arable zone in Finland.

The analysis focuses on a common time period, 1890-1995, at all sites, though some have been updated to 1997 (H. Tuomenvirta, pers. comm. 1998). Earlier data are included from three sites to provide a longer term perspective: Uppsala from 1722 and Stockholm from 1756 (Moberg 1996, A. Moberg pers. comm. 1998) and Helsinki from 1829 (Heino 1994, H. Tuomenvirta pers. comm. 1998). All three of these records have been corrected for urbanisation effects.

\section{Climate change scenarios}

Aside from natural causes (e.g. volcanic eruptions, changes in solar output, earth orbital variations, continental drift or factors internal to the climate system) there is growing evidence to suggest that anthropogenic activities are having a discernible effect on global climate (Santer et al. 1996). Rapid increases in concentration of greenhouse gases (GHGs), especially carbon dioxide, methane, nitrous oxide, ozone and halocarbons, have been observed in the lower atmosphere, which are largely due to fossil fuel combustion, cement manufacture, deforestation and intensive agriculture. These gases are known to trap the sun's energy, and are expected to cause a warming of the surface climate of the globe, though in some regions part of this warming may be offset by concentrations of aerosols in the atmosphere, another bi-product of industrialisation. The magnitude and rate of the expected warming are not well known, especially at regional level, due to the complexity of the climate system. However, estimates with general circulation models (GCMs) of the atmosphere and oceans suggest that northern latitude land areas may warm more rapidly than the global average, while locations in and around the North Atlantic ocean may warm more slowly (IPCC 1996).

In order to summarise recent estimates of the future climate in Finland and surrounding regions, and to obtain a measure of uncertainty in these estimates, a set of temperature and precipitation scenarios were developed as part of the Finnish Research Programme on Climate Change (SILMU) (Carter 1996). The temperature scenarios are depicted in Table 2. They show a gradient of temperature change from the weakest increases expected over Iceland, in the North Atlantic region, with little seasonal variation, to the strongest increases in the most continental part of the region, over Finland, with a marked winter maximum of warming.

Uncertainties concerning future GHG emissions (which determine the radiative forcing of the climate) are accounted for in the scenarios 
Vol. 7 (1998): 161-179.

Table 2. Scenarios of seasonal temperature change by the year $2050\left({ }^{\circ} \mathrm{C}\right)$ for each Nordic country prepared during the Finnish Research Programme on Climate Change (SILMU). Source: based on Carter (1996).

\begin{tabular}{llccccc}
\hline Scenarioo & & Iceland & Denmark & Norway & Sweden & Finland \\
\hline SILMU & Winter & 0.90 & 3.00 & 3.00 & 3.00 & 3.60 \\
Central & Spring & 0.90 & 2.10 & 2.10 & 2.10 & 2.40 \\
& Summer & 0.90 & 1.20 & 1.50 & 1.80 & 1.80 \\
& Autumn & 0.90 & 2.10 & 2.10 & 2.10 & 2.40 \\
SILMU & Winter & 0.30 & 0.86 & 0.86 & 0.86 & 0.90 \\
Low & Spring & 0.30 & 0.60 & 0.60 & 0.60 & 0.60 \\
& Summer & 0.30 & 0.34 & 0.43 & 0.51 & 0.45 \\
& Autumn & 0.30 & 0.60 & 0.60 & 0.60 & 0.60 \\
SILMU & Winter & 1.50 & 4.29 & 4.29 & 4.71 & 5.40 \\
High & Spring & 1.50 & 3.00 & 3.00 & 3.30 & 3.60 \\
& Summer & 1.50 & 1.71 & 2.14 & 2.83 & 2.70 \\
& Autumn & 1.50 & 3.00 & 3.00 & 3.30 & 3.60 \\
\hline
\end{tabular}

Winter (Dec-Feb), Spring (Mar-May), Summer (Jun-Aug), Autumn (Sep-Nov)

by adopting the upper and lower projections defined by the Intergovernmental Panel on Climate Change (IPCC - Leggett et al. 1992). Uncertainties in the global mean temperature response to radiative forcing are also considered, by using the range assumed by the IPCC $\left(1.5-4.5^{\circ} \mathrm{C}\right.$ for an increase in GHG forcing equivalent to a doubling of atmospheric carbon dioxide - IPCC 1996). There are three scenarios: a central scenario (based on composite regional information from GCMs and mid-range assumptions about future atmospheric GHG concentrations and future gobal temperature response), a low scenario (assuming low GHG emissions and low temperature response) and a high scenario (assuming high emissions and high temperature response). Overall, these scenarios provide upper, mid-range and lower estimates of likely future temperature changes in the Nordic region (Carter 1996).

\section{Results}

The analysis consisted of three main steps. First, the GSS, GSE, GSL (growing season length) and
ETS were plotted at all sites and statistical analysis was applied to the common period 18901995 to determine possible trends in the data. Second, to investigate how the growing season during the past century compares with earlier periods, the longer time series from Uppsala, Stockholm and Helsinki were plotted and analysed. Finally, estimates were made of the future growing season under the scenarios of possible temperature change.

\section{The growing season during the past century: 1890-1995}

Plots of GSS, GSE, GSL and ETS during 18901997 were constructed for all sites. The plots for Turku, Finland, are illustrated in Figure 4. In each plot a least squares linear regression line was fitted to provide a first impression of possible trends in the data. The regression lines suggest that GSS has become progressively earlier at all Fennoscandian sites throughout this period (by between 4 and 12 days), with the most marked change occurring between the turn of the century and the decades around the 1940s (Fig. 4a). There is a change towards precocity at 
Seminar in honour of the 100th anniversary of MTT

(a) Growing season start

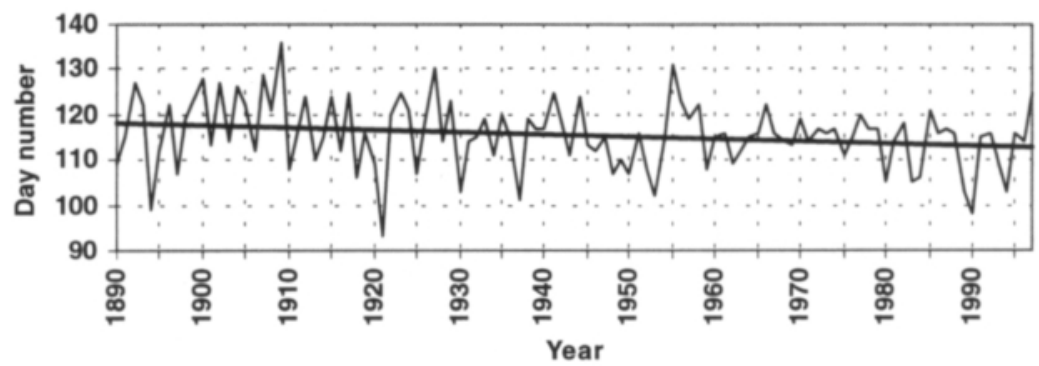

(b) Growing season end

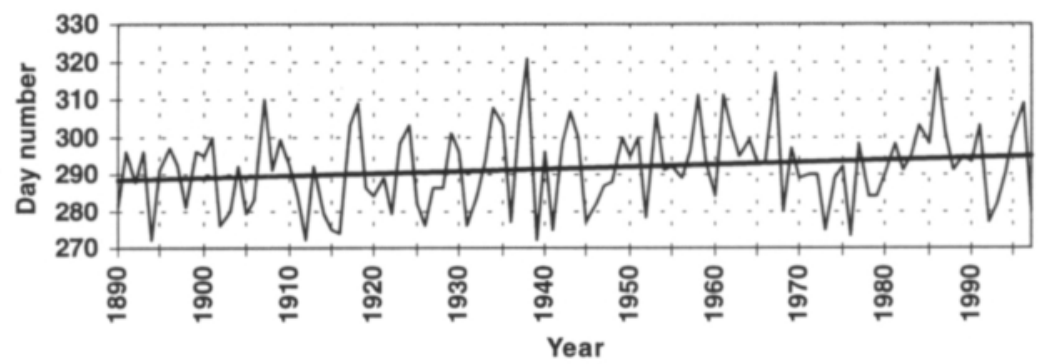

(c) Growing season length

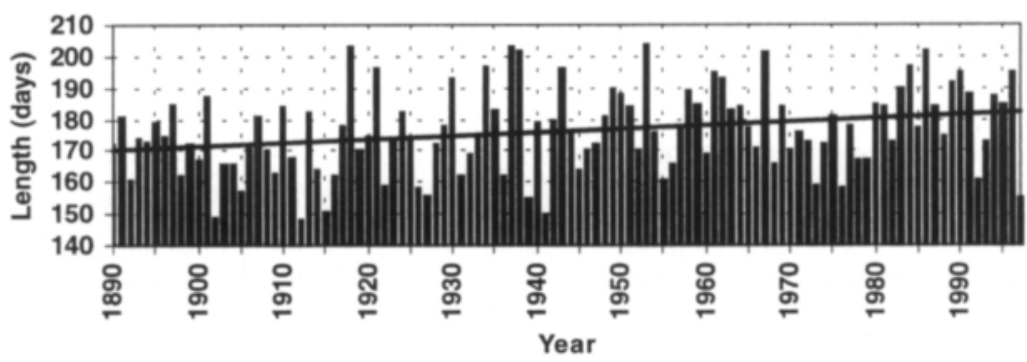

(d) Growing season ETS above $5^{\circ} \mathrm{C}$

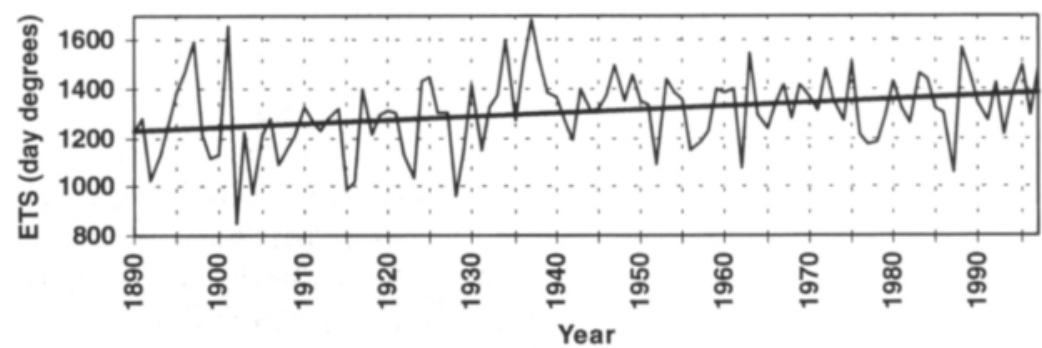

Fig. 4. Computed growing season characteristics at Turku 1890-1997: (a) start, (b) end, (c) duration and (d) effective temperature sum above a base temperature of $5^{\circ} \mathrm{C}$. Least-squares linear regression lines are fitted to each series. 


\section{AGRICULTURAL AND FOOD SCIENCE IN FINLAND}

Vol. 7 (1998): 161-179.

the Icelandic site too up to the $1950 \mathrm{~s}$, but this is partially reversed in the decades up to the present.

At the other end of the growing season there appears to be a concurrent trend towards a more delayed GSE throughout the period (by between 1 and 9 days), again stronger in the early decades of the series (Fig. 4b). The exception is in Iceland, where the GSE has become slightly earlier.

The net effect on GSL has been a strong extension of the season of between 1 and 3 weeks throughout Fennoscandia (cf. Fig. 4c), with a more modest lengthening of 4 days at Stykkishólmur, which disguises a large gain peaking in the 1940 s, followed by a moderate shortening. Concurrent with a lengthening of the growing season, there has also been a general increase in thermal resources as expressed by the ETS. However, this gain was already realised by the 1930 s or 1940s at all sites, and was followed by a decline, although at some sites recent values of ETS have begun to approach those high levels once again (Fig. 4d).

On their own, the trend lines analysed above offer only partial information and can be misleading, as they:

(i) are unable to provide a statistical measure of the strength and significance of a given trend relative to the underlying variability of the data series;

(ii) give undue weight to data points at the beginning and end of a series;

(iii)can disguise possible temporal cycles and other non-linearities in the data series.

Thus, in order to provide a more objective measure of the changes, each time series was divided into three non-overlapping 35-year periods: $1891-1925,1926-1960$ and 1961-1995. To establish whether growing seasons during the most recent period display characteristics that are significantly different from previous periods, the two earlier periods were each compared with the most recent using a student's t-test (2-tailed). The null hypothesis assumed no change in the mean between a given 35-year period and the 1961-1995 period, and the test was conducted at three levels of statistical significance: $P \leq 0.10$, 0.05 and 0.01 . The results are displayed diagrammatically for all sites in Figure 5. For each site the left hand bar represents the difference between the 1891-1925 and 1961-1995 seasons and the right hand bar the difference between the 1926-1960 and 1961-1995 seasons. The significance of a given difference is indicated by shading.

The results provide statistical confirmation of the observations made above, namely, that recent decades at the eight Fennoscandian sites have witnessed a growing season that has lengthened at both ends (with varying degrees of statistical significance) relative to the earliest 35 year period. The GSE has changed more than the GSS in Scandinavia, while the reverse is true in Finland. Overall, significant $(\mathrm{P} \leq 0.1)$ net lengthening has occurred at all sites. There has also been net lengthening relative to the middle 35 years at all sites, but this is not statistically significant. In contrast, further west at Stykkishólmur, there has been a significant shortening $(\mathrm{P} \leq 0.05)$ of the growing season between the middle and recent period although the 1961-1995 mean duration was still longer than in the first period.

The absolute magnitude of lengthening appears to show a declining west-east gradient between Denmark and Finland, though the interannual variability is also higher at the western sites, which explains why there is no clear weakening of the significance levels towards the east. The magnitude of lengthening is a function of the annual cycle of mean daily temperature and is discussed further in a later section.

In common with a lengthening, the growing season also intensified (as expressed by the ETS) between the first 35-year period and the recent period at all sites in Fennoscandia $(\mathrm{P} \leq 0.10)$. However, relative to the middle 35-year period, the recent period has experienced a lower mean ETS at all sites except Turku. Oddly, while none of these differences is significant, this reduction in ETS has occurred in spite of the continued 
Seminar in honour of the 100th anniversary of MTT
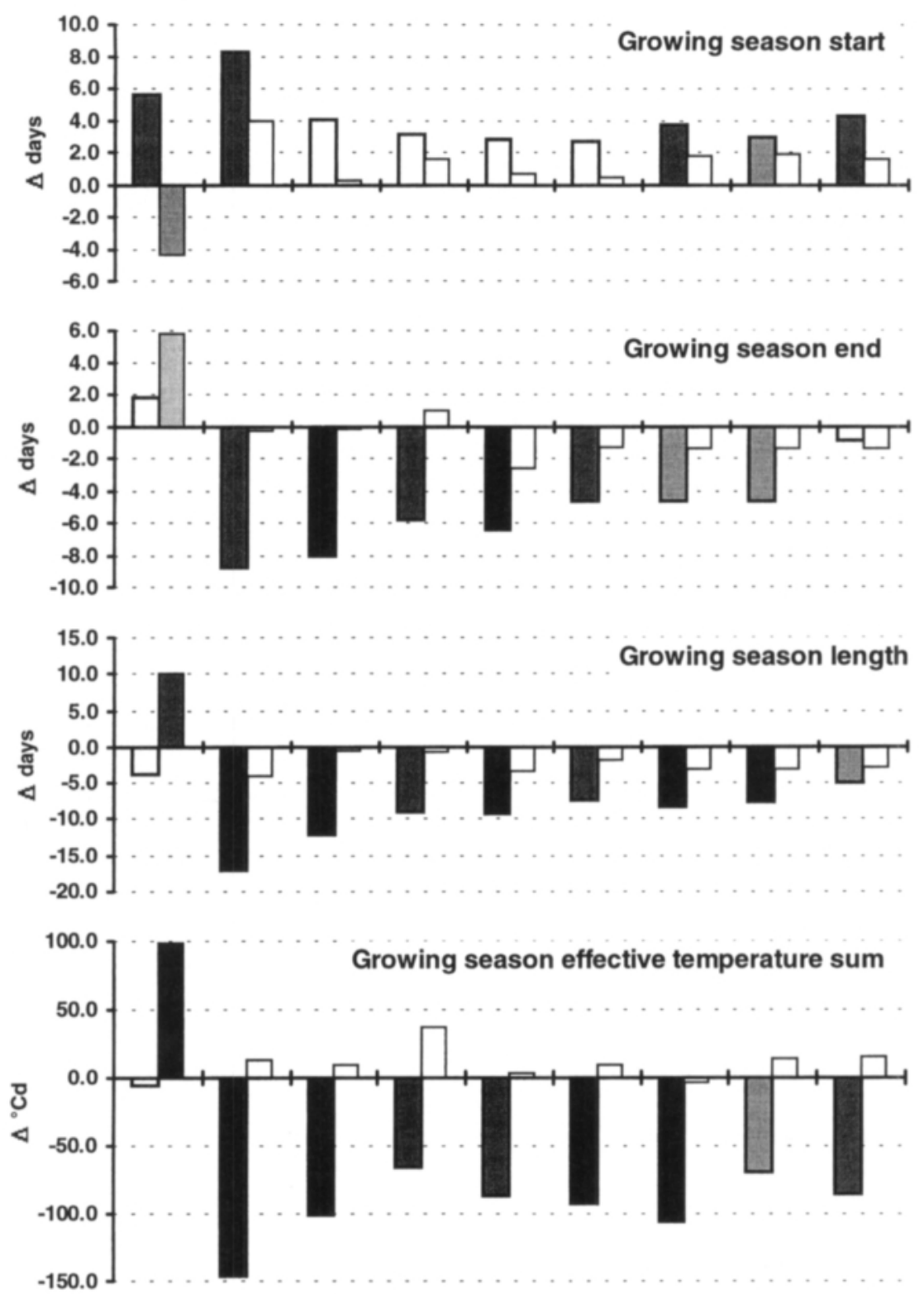

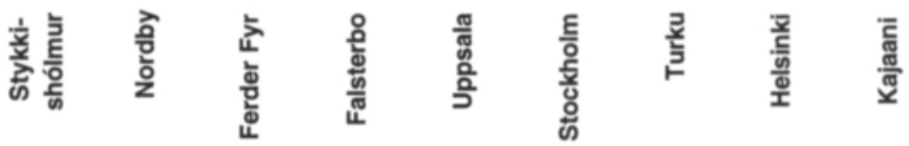

$$
\begin{aligned}
& \begin{array}{|l|l|l}
\hline \text { 1891-1925 } & \square \text { Not significant } \\
\square \text { 1926-1960 } & P \leq 0.10 & P \leq 0.05 \\
& P \leq 0.01
\end{array}
\end{aligned}
$$

Fig. 5. Difference in mean growing season characteristics between 1891-1925 and 1961-1995 (left bar) and between 1926-1960 and 1961-1995 (right bar) at all nine sites (organised west to east). Shaded bars show the level of significance of the difference (t-test). 


\section{AGRICULTURAL AND FOOD SCIENCE IN FINLAND}

Vol. 7 (1998): 161-179.

lengthening of the growing season already noted above.

\section{Longer-term changes in growing season characteristics}

In order to examine whether the growing season during the past century is representative of conditions over the longer term, records from Uppsala (276 years), Stockholm (242 years) and Helsinki (169 years) were also analysed. Each series was divided into non-overlapping 35-year periods, with an opening period made up of the earliest years of the record (1722-1750 at Uppsala, 1756-1795 at Stockholm and 1829-1855 at Helsinki). Plots comparing mean growing season characteristics during each period with those from the recent period, 1961-1995, at the site with the longest record, Uppsala, are depicted in Figure 6.

The results for Uppsala are qualitatively similar to those for the corresponding overlap periods at the other two sites. They indicate that, at least in regions of Fennoscandia bordering the Baltic Sea, the growing season during recent decades has been longer than at any time since the early part of the 19th century (all three sites), and probably longer than at any time since the early 18 th century (Uppsala), with extension in both the spring and autumn, but the greater (more significant) part in the autumn.

In contrast, recent levels of effective temperature sum, while significantly higher than during the late 18th and early 19th centuries (all sites), are significantly lower than those recorded in the second half of the 18th century (Uppsala and Stockholm). Therefore, it appears that the growing season during the late 18th century was somewhat warmer, yet shorter, than in recent times.

\section{The future growing season}

The preceding results indicate that there have been significant changes in growing season length during the past three centuries, so what are the prospects for the future? Before making any specific estimates of future conditions on the basis of detailed scenarios, it is first instructive to examine the sensitivity of the GSL to incremental changes in temperature occurring (unrealistically) throughout the year. The recent World Meteorological Organization (WMO) standard 30-year "normal" period, 1961-1990, is used as the baseline. GSL has been computed for the temperatures observed during this period and then for baseline temperatures adjusted upwards in $1^{\circ} \mathrm{C}$ increments from +1 to $+5^{\circ} \mathrm{C}$. ETS changes were not considered in this part of the analysis. The results are depicted for all nine sites in Figure 7.

They demonstrate that for the same amount of warming, the growing season lengthens by more at maritime locations, which have a weaker annual cycle of temperature, than at continental sites, which have a sharper transition between a cold winter and a warm summer. The average lengthening at Stykkishólmur is about 22 days per $1^{\circ} \mathrm{C}$ warming, compared with 14 days at Uppsala and only 9 days at Kajaani. Note, too, that the magnitude of lengthening per ${ }^{\circ} \mathrm{C}$ is also determined by the proximity of smoothed daily mean temperatures to the critical $5^{\circ} \mathrm{C}$ temperature level. Clearly, as winter temperatures approach this threshold, so an upper limit to the growing season length will be reached. Hence, at the warmest site, Nordby, a warming of as little as $2^{\circ} \mathrm{C}$ would produce a continuous, 365 -day growing season in some years. However, any constraint on the lengthening of the season that this might impose at Nordby is not apparent in Figure 7 , being more than compensated by a marked lengthening in most other years.

For reasons related, inter alia, to regional feedback effects on the climate of snow and ice cover over the land and ocean circulation in the North Atlantic, it is very unlikely that future greenhouse gas-induced changes in climate will be uniform either seasonally or regionally. The SILMU temperature change scenarios for 2050 , which are based on climate model estimates, reflect this non-uniformity in terms of seasonal and 
Seminar in honour of the 100th anniversary of MTT
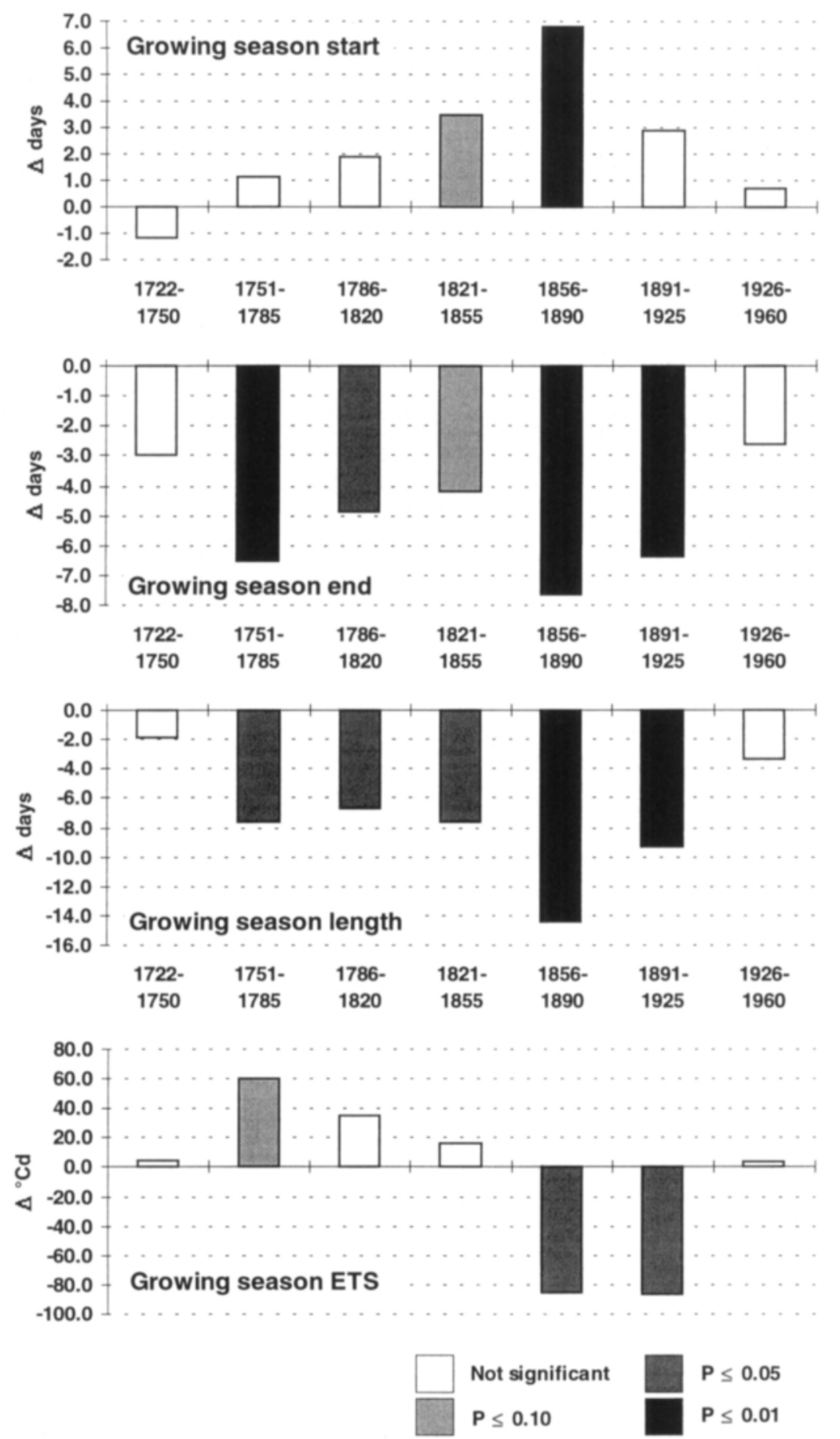

Fig. 6. Differences relative to the recent 1961-1995 period in mean growing season characteristics during non-overlapping 35-year periods back to 1722 at Uppsala (including the 29-year period 1722-1750). Shaded bars show the level of significance of the difference (t-test). 
Vol. 7 (1998): 161-179.

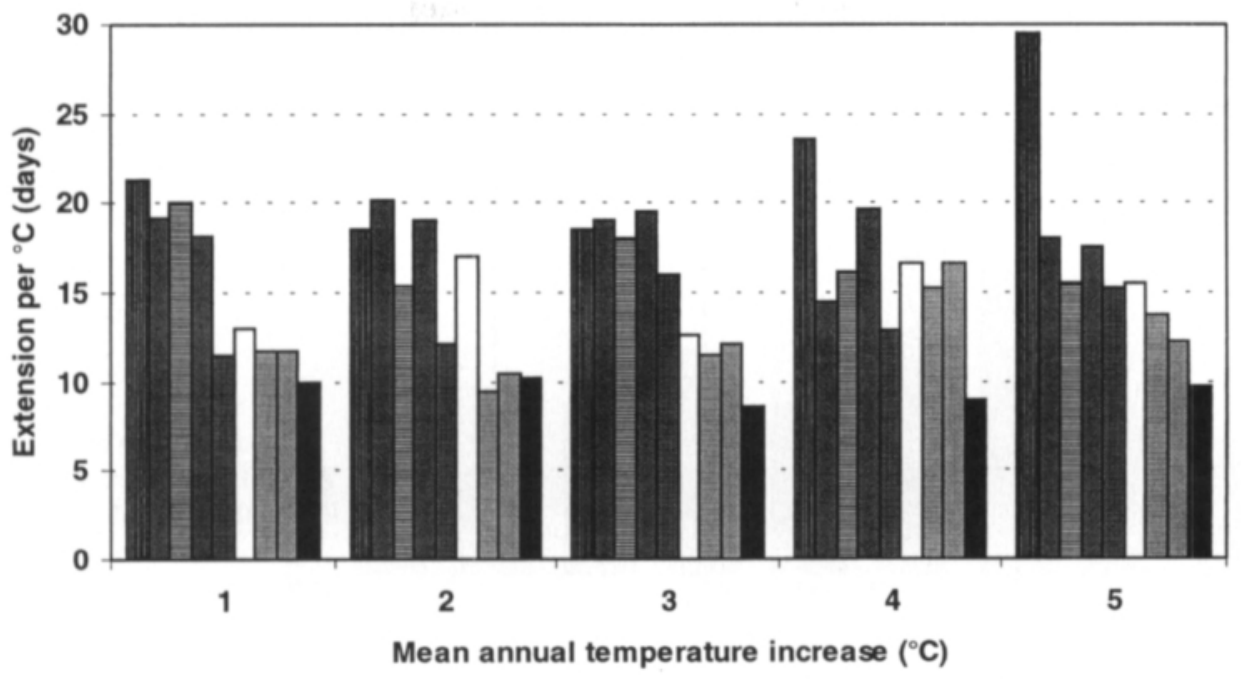

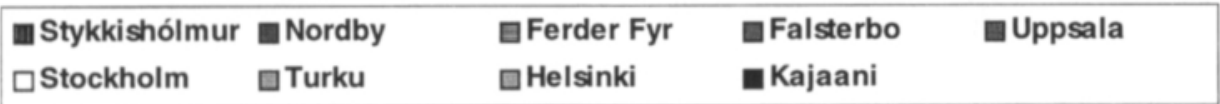

Fig. 7. Sensitivity of mean growing season length to increasing mean annual temperature at $1^{\circ} \mathrm{C}$ increments between 1 and $5^{\circ} \mathrm{C}$ at all sites relative to the 1961-1990 period. Sites are organised from west to east.

national average changes. They also provide a measure of the uncertainty of projections. A significant feature of these scenarios for the present study is the increasing gradient of temperature changes from the maritime west to the continental east (Table 2). This gradient is in contrast to the results presented in Figure 7, which indicated a decrease from west to east in sensitivity of GSL to temperature change. Thus, in broad terms, the largest temperature changes in the Nordic regions are expected in regions where the GSL is least sensitive to these changes, and vice versa.

The outcome of these counteracting effects is presented in Figure 8, which shows the extension of the growing season by 2050 at all sites under the three SILMU scenarios. The extension is greatest at the three southern/western Scandinavian locations (about 6-7 weeks under the central scenario), smaller in eastern Sweden and Finland (approximately 4 weeks) and smallest in Iceland (about 3 weeks). The uncertainty bounds about these estimates are considerable (Fig. 8).

\section{Discussion}

The results presented above indicate that significant changes in growing season characteristics have occurred historically at sites in the Nordic region and are expected to occur in the future. However, there are differences between past and future changes that bear further examination and are described in more detail below. Ultimately, any changes in the growing season can be expected to have consequences for agriculture and ecosystems. Issues relating to the detection, monitoring and prediction of these effects are also discussed in this section. 


\section{AGRICULTURAL AND FOOD SCIENCE IN FINLAND}

Seminar in honour of the 100th anniversary of MTT

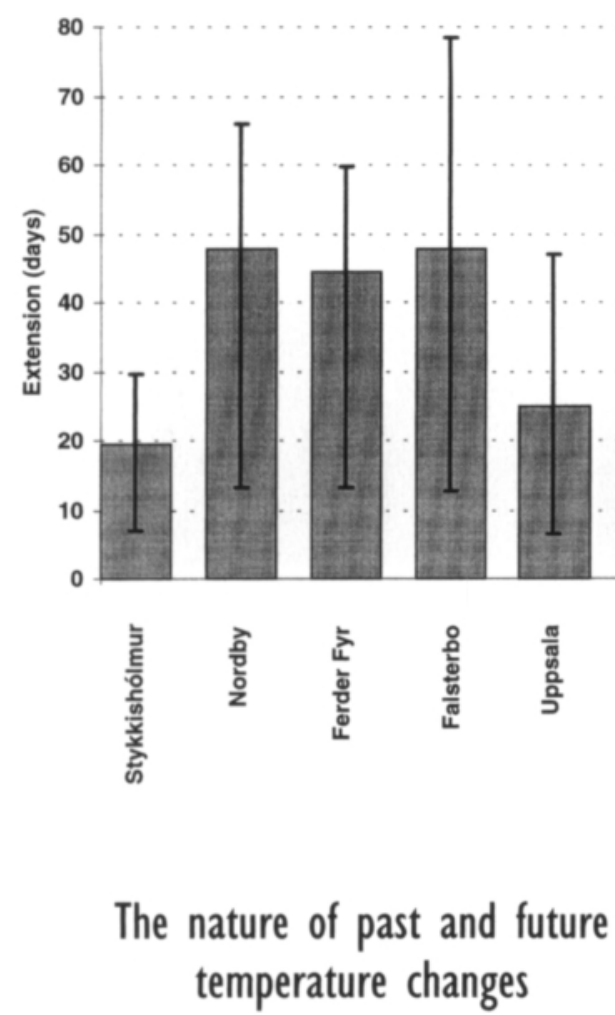

At the outset, it is important to recognise that the analysis conducted in this study has considered only a small subset of representative sites in the Nordic region. A more comprehensive treatment, covering a larger set of reliable, longterm temperature records in the region (possibly interpolated to a regular grid), is required to verify the results presented here. In this way, both the magnitude and the geographical pattern of secular trends in the thermal climate of the growing season could be represented.

A notable result from the analysis of growing season length at sites across Fennoscandia was the prolonged nature of the growing season during the recent 1961-1995 period compared with all previous 35 -year periods analysed. In recent years, responding to claims that a "greenhouse warming" signal should already be apparent in 20th century temperatures over Fennoscandia, climatologists have stressed repeatedly that annual temperatures during the last few decades over Fennoscandia have not been exception- al with respect to longer-term variability, and indeed have not returned to the high levels recorded during the 1930s and 1940s (Heino 1994, Tuomenvirta and Heino 1996, Moberg 1996). This observation is borne out by the ETS results, which show peak values during the 1940 s at most sites (and higher values still during the late 18th and early 19th centuries at Uppsala and Stockholm).

However, unlike ETS, which is influenced by changes in temperature throughout the growing season, the start and end (and hence the length) of the growing season are affected by temperature changes only during the short periods when the $5^{\circ} \mathrm{C}$ temperature threshold is breached in the spring and autumn. Given that GSL is being computed here using temperatures interpolated from monthly means, the reasons for changes in GSL are therefore to be found in changes of temperature during those months having mean temperatures close to $5^{\circ} \mathrm{C}$.

This is illustrated in Figure 9, which displays monthly mean temperatures relative to 19611995 during two historical periods, 1891-1925 and 1926-1960, at Uppsala. Temperatures during the earlier period were cooler than the re- 
Vol. 7 (1998): 161-179.

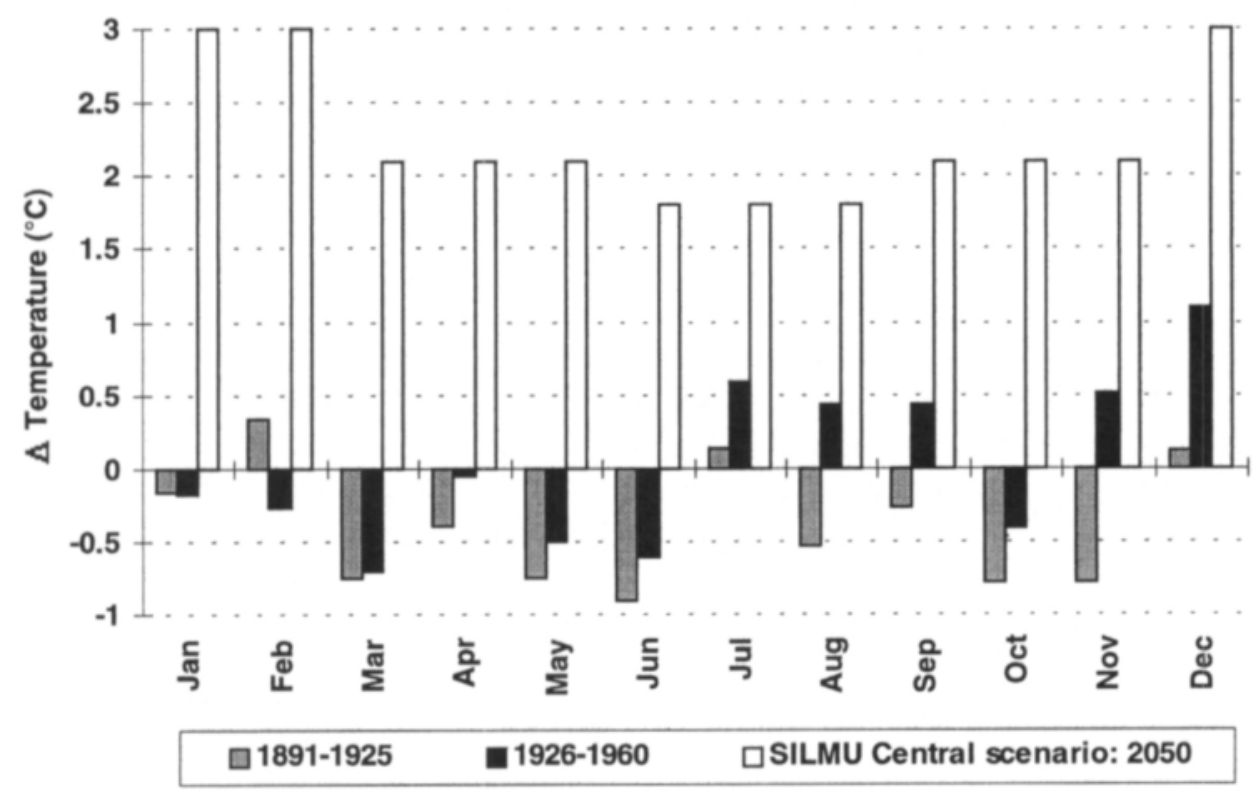

Fig. 9. Mean monthly temperatures relative to 1961-1995 at Uppsala: 1891-1925, 1926-1960 and under the Finnish Research Programme on Climate Change (SILMU) Central scenario for the period centred around 2050.

cent period during all months except February, July and December, which explains the lower ETS and shorter growing season in that period. In contrast, temperatures during the period 19261960 were warmer than in the recent period during July-September, contributing to the greater ETS recorded, while temperatures in May and October, the key months determining the start and end of the growing season, were both cooler than in the recent period, explaining the shorter GSL. Furthermore, scrutiny of the extended Uppsala record indicates that mean monthly temperatures during 1961-1995 were at the highest level since at least the mid-18th century in the 3 months April, May and October.

Figure 9 also shows the temperature changes projected for the 2050s at Uppsala under the SILMU Central scenario. The seasonal pattern of future temperature change is different from that observed over the past century, which perhaps calls into question an anthropogenic signal in the historical temperature record. Obviously, with increased temperatures projected for all months, both ETS and GSL would increase.

The large magnitude of temperature change by the 2050 s also implies a rapid rate of growing season lengthening. For instance, at Uppsala the GSL is calculated to increase by some 4 days per decade. This is one third faster than the increase of about 3 days per decade recorded between the periods 1898-1932 and 1933-1967, which witnessed the most rapid change in 35year averaged GSL during the entire 276-year record. Thus, estimates of the rate of future growing season lengthening appear to be unprecedented in the last three centuries, at least in regions adjacent to the Baltic Sea. However, it should also be noted that this is a central estimate: the SILMU Low and High scenarios imply an uncertainty range of growing season lengthening of between about 1 and 7.5 days per decade.

A final point concerns the climatological significance of the growing season changes computed above. The coefficient of determination 


\section{AGRICULTURAL AND FOOD SCIENCE IN FINLAND}

Seminar in honour of the 100th anniversary of MTT

$\left(\mathrm{R}^{2}\right)$ between GSL and ETS was computed for the 106-year period $1890-1995$ at all nine sites. The results indicate a surprisingly weak positive relationship between the length and intensity of the growing season at all Fennoscandian sites $\left(\mathrm{R}^{2}\right.$ varying from 0.13 to 0.36 ). In contrast, at Stykkishólmur a long growing season is commonly associated with a high value of ETS $\left(\mathrm{R}^{2}=0.53\right)$, which suggests that there may be some autocorrelation between spring, summer and autumn temperatures in Iceland that is not as well-defined at the Fennoscandian sites. A possible physical explanation for this may be the presence or absence of winter snowcover. Whereas mild winters are characterised by little or no snowcover in lowland Iceland, severe winters tend to have prolonged snowcover followed by a late spring and cool summer, related to the slow thawing and warming of the predominantly peaty soils. Indeed, this phenomenon has even been applied in predicting annual hay yields, using a statistical model based on the mean OctoberApril temperature prior to the growing season (Bergthórsson et al. 1988). A cold winter invariably precedes a low hay yield, and vice versa.

\section{Implications for agriculture and ecosystems}

On its own, the length of the growing season is insufficient as an indicator of the thermal requirements of biological organisms; a measure of intensity such as ETS is usually required as well. Nevertheless, knowledge of the GSL may offer insights into the timing of critical events in the biological calendar. The foregoing analysis has identified a systematic lengthening of the growing season across Fennoscandia during the past century. The challenge presented by these results is to identify responses in the natural and managed environment that would be the logical outcome of such changes. A number of types of indicator of a changing growing season that either have been studied previously or might merit further attention are listed below.
1. The timing of phenological events in natural and cultivated plant species. The phenology of plant species is known to be closely related to temperature, and good quality phenological observations exist in the Nordic countries. For example, a database of long-term phenological observations for 46 plant taxa in Finland is presented by Lappalainen and Heikinheimo (1992). Bud burst dates are analysed in more detail for 11 species by Heikinheimo and Lappalainen (1997) and for birch by Häkkinen et al. (1995). However, caution should be exercised in interpreting any trends, as the reliability of long-term phenological records depends on the consistency of observations (Linkosalo et al. 1996). Phenological data are also available for cultivated crops (e.g. data from national variety trials). Like the natural species, these data should be screened for long-term consistency. Note also that phenological events are likely to be related not only to the start of the growing season but also to its intensity.

2. Other biotic indicators of change. There is growing evidence for other recent trends in the natural environment that are consistent with a changing growing season. European amphibians and birds have been breeding consistently earlier over the past two to three decades (Forchhammer et al. 1997) and satellite observations during the decade 19811991 suggest an increase in plant growth associated with a lengthening of the active growing season in the region between $45^{\circ}$ and $70^{\circ} \mathrm{N}$ (Myneni et al. 1997).

3. Human responses to change. The potential timing of farm operations, especially sowing and harvest, represent a human response to the perception of the growing season. For example, in many regions of northern Europe, spring sowing occurs as soon as snow cover disappears and soil conditions are suitable for seedbed preparation. If the start of the thermal growing season has become earlier in the spring, then some evidence of earlier sowing of spring cereals might be expected in records from long-term variety trials or other sources 
Vol. 7 (1998): 161-179.

reflecting standard farming practices. Similarly, the harvesting of root crops, tubers and some grass species is often determined by the timing of low temperatures in the autumn, so a later end to the growing season might imply a later date of harvest.

4. Abiotic indicators of change. Other surface observations can also be used as corroborating evidence for changes in the growing season. For instance, surface-based measurements of the amplitude and annual cycle of atmospheric $\mathrm{CO}_{2}$ concentration over the last two decades at northern high latitudes indicate an advance in the drawdown of $\mathrm{CO}_{2}$ in the spring of up to 7 days consistent with earlier biological activity (Keeling et al. 1996). Furthermore, an approximate $10 \%$ reduction in annual snow cover has been observed by satellites over a similar region between 1973 and 1993, with the deficit of snow particularly apparent in spring (Groisman et al. 1994). Similar trends have also been observed at sites in Finland (Heino 1994,
Tuomenvirta and Heino 1996). Finally, another sensitive indicator of spring temperature conditions is the breakup date of sea and lake ice. These dates have been recorded since at least the first part of the 19th century in Nordic countries (e.g. see Kuusisto 1989), and provide an independent set of long-term records for comparison with other indicators.

Further analysis of some of these indicators could help to establish whether or not there have been tangible biotic, abiotic or human responses during the past century to a lengthening growing season in Fennoscandia. Clearly, should these trends continue or accelerate, one of the traditional constraints on agricultural production in the Nordic region may gradually disappear.

Acknowledgements. I am grateful to Heikki Tuomenvirta of the Finnish Meteorological Institute and Anders Moberg of Stockholm University for supplying additional temperature data, and to Riitta Saarikko for assistance in translating the summary.

\section{References}

AGPM 1987. Besoins en temperatures des varietes de maĩs. AGPM - Info Techniques No. 67. Paris: Association Générale des Producteurs de Maĩs (in French).

Bergthórsson, P., Björnsson, H., Diyrmundsson, O., Gudmundsson, B., Helgadóttir, A. \& Jónmundsson, J.V. 1988. The effects of climatic variations on agriculture in Iceland. In: Parry, M.L. et al.(eds.). The impact of climatic variations on agriculture. Volume 1. Assessments in cool temperate and cold regions. Dordrecht: Kluwer. p. 381-509.

Brooks, C.E.P. 1943. Interpolation tables for daily values of meteorological elements. Quarterly Journal of the Royal Meteorological Society 69: 160-162.

Carter, T.R. 1996. Developing scenarios of atmosphere, weather and climate for northern regions. Agricultural and Food Science in Finland 5: 235-249.

CETIOM 1986. Cahier Technique Tournesol: Atlas Agrométéo. Paris: Centre Technique Interprofessionel des Oléagineux Métropolitains (in French).

- 1987. Cahier Technique Soja: Atlas Agrométéo. Paris: Centre Technique Interprofessionel des Oléagineux Métropolitains (in French).

de Smet, P.A.M. \& Heuvelmans, E. 1997. Development of the European land use data base. In: Posch, M. et al. (eds.). Calculation and Mapping Critical Thresholds in Europe: Status Report 1997. RIVM Report No. 259101007, Coordination Center for Effects, National Institute of Public Health and the Environment, Bilthoven, The Netherlands. p. 41-46.

FAO 1978. Report on the agro-ecological zones project. Volume 1: Methodology and results for Africa. World Soil Resources Report 48. Rome: Food and Agriculture Organization. $158 \mathrm{p}$.

Forchhammer, M.C., Post, E. \& Stenseth, N.C. 1997. Breeding phenology and climate. Nature 391: 29-30.

Frich, P., Alexandersson, H., Ashcroft, J., Dahlström, B., Demarée, G.R., Drebs, A., van Engelen, A.F.V., Førland, E.J., Hanssen-Bauer, I., Heino, R., Jónsson, T., Jonasson, K., Keegan, L., Nordli, P.Ø., Schmith, T., Steffensen, P., Tuomenvirta, H. \& Tveito, O.E. 1996. North Atlantic Climatological Dataset (NACD Version 1) - Final Report. Danish Meteorological Institute Scientific Report 96-1, Copenhagen: Danish Meteorological Institute. 47 p. + appendices and diskettes.

Gallagher, J.N. 1979. Field studies of cereal leaf growth. I. Initiation and expansion in relation to temperature and ontogeny. Journal of Experimental Botany 30: 625-636. 


\section{Seminar in honour of the 100th anniversary of MTT}

Goudriaan, J. 1988. Landbouw en klimaat. Lucht en Omgeving March: 6-8 (in Dutch).

Groisman, P.Ya., Karl, T.R. \& Knight, T.W. 1994. Observed impact of snow cover on the heat balance and the rise of continental spring temperatures. Science 263: 198-200.

Hăkkinen, R., Linkosalo, T. \& Hari, P. 1995. Methods for combining phenological time series: application to bud burst in birch (Betula pendula) in Central Finland for the period 1896-1955. Tree Physiology 15: 721-726.

Heikinheimo, M. \& Lappalainen, H. 1997. Dependence of the flower bud burst of some plant taxa in Finland on effective temperature sum: implications for climate warming. Annales Botanici Fennici 34: 229-243.

Heino, R. 1994. Climate in Finland during the period of meteorological observations. Finnish Meteorological Institute Contributions No. 12. Helsinki: Finnish Meteorological Institute. 209 p.

Hough, M.N. 1975. Mapping areas of Britain suitable for maize on the basis of temperature. ADAS Quartery Review 18: 64-72.

IPCC 1996. Technical summary. In: Houghton, J.T. et al. (eds.). Climate Change 1995. The Science of Climate Change. Contribution of Working Group I to the Second Assessment Report of the Intergovernmental Panel on Climate Change. Cambridge: Cambridge University Press. p. 9-49.

Keeling, C.D., Chin, J.F.S. \& Whorf, T.P. 1996. Increased activity of northern vegetation inferred from atmospheric $\mathrm{CO}_{2}$ measurements. Nature 382: 146-149.

Kleemola, J. 1991. Effect of temperature on phasic development of spring wheat in northern conditions. Acta Agriculturae Scandinavica 41: 275-283.

Kooman, P.L. 1995. Yielding ability of potato crops as influenced by temperature and daylength. Ph.D. Thesis. Wageningen: Wageningen Agricultural University, The Netherlands. $155 \mathrm{p}$.

Kuusisto, E. 1989. Snow and ice - nonrenewable natural resources in the future? In: Huttunen, L. (ed.). Conference on Climate and Water. Volume 1. Publications of the Academy of Finland 9/89. Helsinki: Government Printing Centre. p. 300-318.

Lallukka, U., Rantanen, O. \& Mukula, J. 1978. The temperature sum requirement of barley varieties in Finland. Annales Agriculturae Fenniae 17: 185-191.

Lappalainen, H. \& Heikinheimo, M. 1992. Relations between climate and plant phenology. Part 1. Survey of plant phenological observations in Finland from 1896 to 1965. Meteorological Publications No. 20. Helsinki: Finnish Meteorological Institute. 74 p.

Leemans, R. \& Solomon, A.M. 1993. The potential re- sponse and redistribution of crops under a doubled $\mathrm{CO}_{2}$ climate. Climate Research 3: 79-96.

Leggett, J., Pepper, W.J. \& Swart, R.J. 1992. Emissions scenarios for the IPCC: an update. In: Houghton, J.T. et al. (eds.). Climate Change 1992: The Supplementary Report to the IPCC Scientific Assessment. Cambridge University Press, Cambridge. p. 75-95.

Linkosalo, T., Hăkkinen, R. \& Hari, P. 1996. Improving the reliability of a combined phenological time series by analyzing observation quality. Tree Physiology 16 : 661-664.

Meteorological Office 1965. Tables for the evaluation of daily values of accumulated temperature above and below $42^{\circ} \mathrm{F}$ from daily values of maximum and minimum temperature. Meteorological Office Leaflet No. 10, London: HMSO. 10 p.

Moberg, A. 1996. Temperature variations in Sweden since the 18th century. Department of Physical Geography, Stockholm University Dissertation Series No. 5. $98 \mathrm{p}$.

Myneni, R.B., Keeling, C.D., Tucker, C.J., Asrar, G. \& Nemani, R.R. 1997. Increased plant growth in the northern high latitudes from 1981 to 1991. Nature 386: 698-702.

Nuttonson, M.Y. 1955. Wheat-climate relationships and the use of phenology in ascertaining the thermal and photothermal requirements of wheat. American Institute of Crop Ecology, Washington, D.C. 388 p.

Saarikko, R.A. \& Carter, T.R. 1996. Phenological development in spring cereals - response to temperature and photoperiod under northern conditions. European Journal of Agronomy 5: 59-70.

Santer, B.D., Wigley, T.M.L., Barnett, T.P. \& Anyamba, E. 1996. Detection of climate change and attribution of causes. In: Houghton, J.T. et al. (eds.). Climate Change 1995. The Science of Climate Change. Contribution of Working Group I to the Second Assessment Report of the Intergovernmental Panel on Climate Change. Cambridge: Cambridge University Press. p. 407-443.

Sarvas, S. 1972. Investigations on the annual cycle of development of forest trees. Active period. Communications Instituti Forestalis Fenniae 76: 1-110.

Taylor, J.A. 1976. Upland climates. In: Chandler, T.J. \& Gregory, S. (eds.). The Climate of the British Isles. London: Longman. p. 264-287.

Tuomenvirta, H. \& Heino, R. 1996. Climatic changes in Finland - recent findings. Geophysica 32: 61-75.

Venäläinen, A. \& Nordlund, A. 1988. Kasvukauden ilmastotiedotteen sisältö ja käyttö. Finnish Meterological Institute Report No. 1988:6. Helsinki: Finnish Meterological Institute. 63 p. (in Finnish). 


\title{
AGRICULTURAL AND FOOD SCIENCE IN FINLAND
}

Vol. 7 (1998): 161-179.

\section{SELOSTUS}

\section{Termisen kasvukauden muutokset Pohjoismaissa viimeisen vuosisadan aikana ja tulevaisuudessa}

\author{
Timothy R. Carter \\ Maatalouden tutkimuskeskus
}

Termisen kasvukauden (ajanjakso, jolloin vuorokauden keskilämpötila ylittää $+5^{\circ} \mathrm{C}$ ) alkua, loppua ja kestoa tarkasteltiin edellisen sadan vuoden aikana (18901995) yhdeksällä koepaikalla Pohjoismaissa. Tilastollisia vertailuja tehtiin kolmen perättäisen 35-vuotisjakson välillä. Tulokset osoittavat, että kasvukausi piteni merkittävästi kaikilla koepaikoilla vuosina 1891-1925 ja 1926-1960. Kasvukauden piteneminen on jatkunut tähän päivään saakka, joskin aiempaa hitaampana, kaikilla muilla paitsi islantilaisella koepaikalla. Kasvukauden tehokkuus kuvattuna tehoisana lämpösummana $\left(+5^{\circ} \mathrm{C}\right.$ ylittävien vuorokausikeskilämpötilojen summa) kasvoi kaikilla koepaikoilla kahden ensimmäisen jakson aikana, mutta pieneni jonkin verran viimeisellä jaksolla kaikkialla paitsi Turussa.
Saavuttaessa 2050-luvulle kasvukauden arvioidaan pidentyneen kaikilla koepaikoilla, kun arvion perustaksi valitaan kolme erilaista skenaariota ilmaston odotetusta lämpenemisestä. "Keskiarvioskenaarion" mukaisessa ennusteessa kasvukausi pitenisi eniten eteläisessä ja läntisessä Skandinaviassa (7-8 viikkoa) ja vähiten Suomessa (4 viikkoa) ja Islannissa (3 viikkoa).

Kasvukauden piteneminen viimeisen sadan vuoden aikana on todennäköisesti jättänyt jälkensä luonnontilaisiin ja hoidettuihin ekosysteemeihin. Joitakin merkkejä bioottisista ja abioottisista vaikutuksista onkin jo havaittavissa, mutta monia indikaattoreita pitkän ajan muutoksesta ei ole vielä tarkasteltu. 